\title{
Causal Connections between Water Quality and Land Use in a Rural Tropical Island Watershed
}

\section{Rural Tropical Island Watershed Analysis}

Guy Ragosta, ${ }^{1,8}$ Carl Evensen, ${ }^{2}$ E. R. Atwill, ${ }^{3}$ Mark Walker, ${ }^{4}$ Tamara Ticktin, ${ }^{5}$ Adam Asquith, ${ }^{6}$ and Kenneth W. Tate ${ }^{7}$

${ }^{1}$ Surfing Medicine International 501(c)(3), 5-5785A Kuhio Highway, Hanalei, HI 96714

${ }^{2}$ Department of Natural Resources and Environmental Management, University of Hawaii at Manoa, 1911 East West Road, Sherman 101, Honolulu, HI 96822

${ }^{3}$ School of Veterinary Medicine, University of California, Davis, 18830 Road 112, Tulare, CA 93274

${ }^{4}$ Department of Natural Resources and Environmental Science, University of Nevada, Reno, Mail Stop 370, 1664 North Virginia Street, Reno, NV 89557

${ }^{5}$ Botany Department, University of Hawaii at Manoa, 3190 Maile Way, Honolulu, HI 96822

${ }^{6}$ Kauai Agricultural Research Station, University of Hawaii Sea Grant College Program, 7370-A Kuamoo Road, Kapaa, HI 96766

${ }^{7}$ Department of Plant Sciences, University of California, Davis, Mail Stop One, One Shields Avenue, Davis, CA 95616

${ }^{8}$ Surfing Medicine International 501(c)(3), P.O. Box 548, Waialua, HI 96791

\begin{abstract}
We examined associations between riparian canopy cover, presence or absence of cattle, rainfall, solar radiation, month of year, dissolved oxygen, turbidity, salinity, and Enterococcus concentrations in riparian surface soils with Enterococcus geometric mean in-stream water concentrations at Waipā watershed on the north side of the Hawaiian island Kaua'i. Each 1\% decrease in riparian canopy cover was associated with a 4.6 most probable number (MPN)/100 ml increase of the geometric mean of Enterococcus in stream water $(P<0.05)$. Each unit decrease in salinity (ppt) was associated with an increase of Enterococcus by 68.2 MPN/ $100 \mathrm{ml}$ in-stream water geometric mean concentrations $(P<0.05)$. Month of year was also associated with increases in stream water Enterococcus geometric mean concentrations $(P<0.05)$. Reducing riparian canopy cover is associated with Enterococcus increases in stream water, suggesting that decreasing riparian vegetation density could increase fecal bacteria surface runoff.
\end{abstract}

Keywords: tropical islands, Enterococci, streams

\section{INTRODUCTION}

Causes of fecal pollution of tropical island stream waters include lack of management of cattle, agricultural, and urban runoff and discharges, and direct deposition of

Published online: March 19, 2010

Correspondence to: Guy Ragosta, e-mail: surfingmedicine@gmail.com livestock fecal material in stream waters. Infectious disease transmission may occur via surface waters when these waters become contaminated with fecal material from humans, livestock, and wildlife (USEPA, 2003). Poor microbial water quality, sanitation, and hygiene account for some 1.7 million deaths a year worldwide, mainly through infectious diarrhea (Ashbolt, 2004). 
High Enterococcus concentrations in tropical island lower elevation stream waters and soils could be a result of extensive land degradation by ungulates and people (Hardina and Fujioka, 1991; Fujioka et al., 1999). However, potential for Enterococcus to survive and reproduce in warm, humid tropical island environments creates uncertainty about the use of Enterococcus as an indicator of fecal-derived water contamination. Background environmental levels of Enterococcus in tropical islands are potentially much higher than under conditions studied to establish USEPA guidelines in Boston Harbor, MA; New York City, NY; and New Orleans, LA (Shibata et al., 2004). Also, some researchers state that Enterococcus occurs naturally in nonfecal sources, such as soil and water on tropical islands, and that Enterococcus is not valid as an indicator of contamination by human and animal feces on tropical islands (Hardina and Fujioka, 1991; Fujioka, 2001). However, positive enterococcal surface protein (esp) gene assays of environmental samples collected in Hanalei watershed of Kaua'i indicated that some Enterococci originated from human feces (Knee et al., 2008).

U.S. Environmental Protection Agency (USEPA) recommends testing for Enterococcus for fresh and marine waters, since presence of Enterococcus has been shown to be directly correlated with gastrointestinal illness rates associated with recreational contact (USEPA, 1986). Byappanahalli and Fujioka (2004) stated that elevated Enterococcus in tropical island surface waters that exceeded USEPA standards was due to runoff from soil that contained free-living cells, producing false-positive results with respect to implied contamination by feces of warmblooded animals and the microbiological safety of water supplies. The water quality criterion for Enterococci is a geometric mean concentration of 33 of the most probable number (MPN)/100 $\mathrm{ml}$ in fresh water, and $35 \mathrm{MPN} /$ $100 \mathrm{ml}$ in marine water, of five samples collected over a 30-day period. We examined relationships between Enterococcus water concentrations and land use at Waipā watershed on the Hawaiian Island of Kaua'i (Fig. 1) for monitoring and regulatory enforcement based upon a geometric mean of multiple sample collections per month. Evaluation of Enterococcus as a reliable indicator of surface water fecal contamination is required to establish that this monitoring metric is effective for protecting human health and guiding implementation of water quality management practices.

\section{OBJECTIVES}

The overall study purpose was to evaluate how reductions in riparian canopy cover and presence or absence of cattle are associated $(P<0.05)$ with Enterococcus in samples from stream water. A positive association $(P<0.05)$ between presence of cattle $(<100 \mathrm{~m})$ and Enterococcus geometric mean in-stream water concentrations may indicate that the presence of cattle within $100 \mathrm{~m}$ of monitoring sites increases fecal concentrations to in-stream water. A negative association $(P<0.05)$ between decreasing riparian canopy cover and Enterococcus geometric mean concentrations in stream water may indicate that a lower riparian vegetation density allows for increased fecal surface runoff. We also assessed the associations $(P<0.05)$ of Enterococcus geometric mean in-stream water concentrations with rainfall, solar radiation, month of year, dissolved oxygen, turbidity, and salinity concentrations in water in order to determine how other watershed variables are associated to Enterococcus geometric mean concentrations in Waipā Stream water.

\section{Methods}

\section{Study Site Description}

Our monitoring sites were in Waipā watershed on the rural Hawaiian island Kaua'i (Fig. 1, 2). The watershed encompasses about 650 hectares from sea level to Mamalahoa Summit at $1141 \mathrm{~m}$ above sea level. Middle to upper elevation Waipā riparian zones, unmanaged and uninhabited by people, provide an environment where nonnative invasive plants such as Psidium cattleianum Sabine and Psidium guajava Linnaeus have spread rapidly, in part because they are food sources for horses, pigs, rats, and birds, which eat the fruits and disperse seeds from these plant species. Lower elevation Waipā contains streamflow diversions and water transport via ditches used to irrigate the vegetable taro (Colocasia esculenta [Linnaeus] Schott). The watershed near sea level also has several rural residences, a two-lane paved road, a community center, small agricultural plots, about 50 rodeo cattle that graze an approximately 2 -hectare paddocked pasture $(<100 \mathrm{~m}$ from sites 1 and 2), and a few cattle and horses that stay outside the paddock ( $<100 \mathrm{~m}$ from site 3$)$. Surface soil in Waipā's riparian zones varies in texture from extremely 


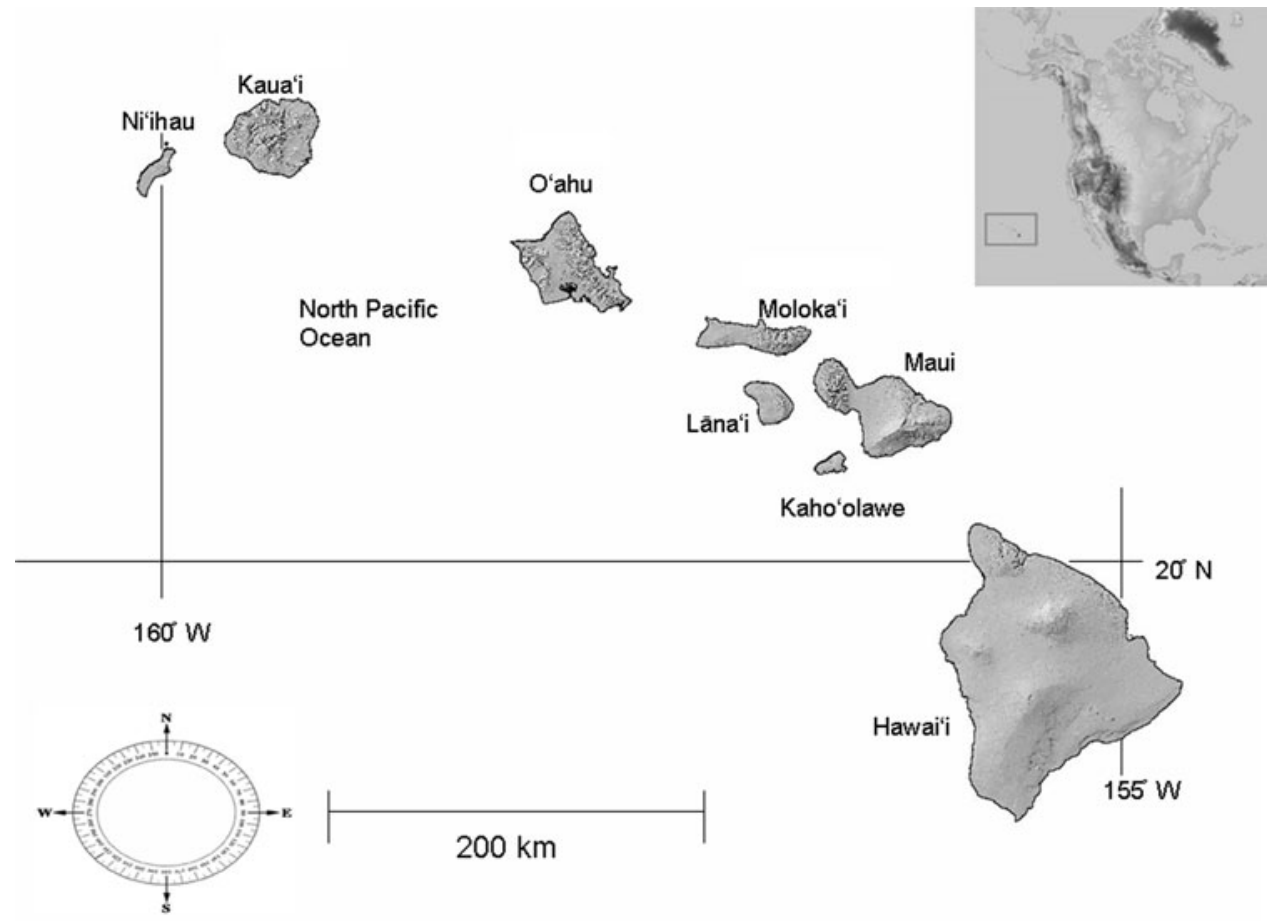

Figure 1. Map of Hawaiian Islands.

compacted loamy sand soils along the cattle pasture irrigation diversion ditch, near site 2 around sea level, to rocks and boulders mixed with silty clay loam soils in the upper elevations of the watershed. Cattle grazed along Kapalikea tributary until the late 1960's when land managers confined remaining cattle around sites 1,2 , and 3 . During the study period, most of the approximately 50 cattle congregated and grazed daily within $100 \mathrm{~m}$ of sites 1 and 2, with a lesser density of cattle grazing $<100 \mathrm{~m}$ from site 3 (outside the approximately 2-hectare paddock surrounding sites 1 and 2). Roads and other structures make it more difficult for cattle to cross from site 2 (located at the end of a cattle pasture irrigation diversion ditch) to site 1 (located at Waipā Stream mouth). Residents may also contribute Enterococci from leaching sewage to site 1 at sea level, which is the only site below residences at Waipā. Cattle were never present at sites 4, 5, 6, or 7 due to confinement and active management, and rugged topography too difficult for cattle to access. The irrigation diversion ditch that runs along the cattle pasture near sea level drains surface runoff to site 2, which exits via a culvert into Waipā Stream mouth at site 1, flowing directly into Hanalei Bay.

\section{Site and Plot Design}

We established 12 riparian monitoring plots, seven stream monitoring sites, and two weather stations in the Waipā watershed. All plots were established to characterize riparian canopy cover (\%) and to collect composite surface soil samples for Enterococcus concentration (MPN/g) analysis. We randomly located riparian plots within the lower $(n=4)$, mid- $(n=4)$, and upper $(n=4)$ sections of Waipā Stream $(10 \times 10 \mathrm{~m}$ plot size $)$, based on initial assessments of canopy cover during which we found stratified sections of specific dominant canopy species. Hibiscus tiliaceus Linnaeus canopy dominated (almost $100 \%$ cover) the lower Waipā Stream near sea level. The mid-elevations were dominated by a mix of Mangifera indica Linnaeus and Psidium spp. The upper elevations were dominated by almost $100 \%$ canopy cover of P. guajava and P. cattleianum, with small amounts of Metrosideros polymorpha Gaudichaud and Freycinetia arborea Gaudichaud.

In the two major tributaries entering mid-Waipā Stream, we located soil sampling plots randomly based on the length of Kapalikea tributary $(5 \times 5 \mathrm{~m}, n=4)$, and Kolopua tributary $(5 \times 5 \mathrm{~m}, n=4)$. Randomly located plots were also established near sea level in the cattle pasture along an irrigation water transport ditch, which was covered with about $14 \%$ canopy that drains surface water via a culvert directly into Waipā Stream mouth $(10 \times 10 \mathrm{~m}, n=4)$ (Fig. 2). Each of seven stream water quality monitoring sites (Fig. 2) were established to provide data at the end of a cattle pasture diversion ditch $(n=1)$, along stratified elevation and canopy sections of Waipā 


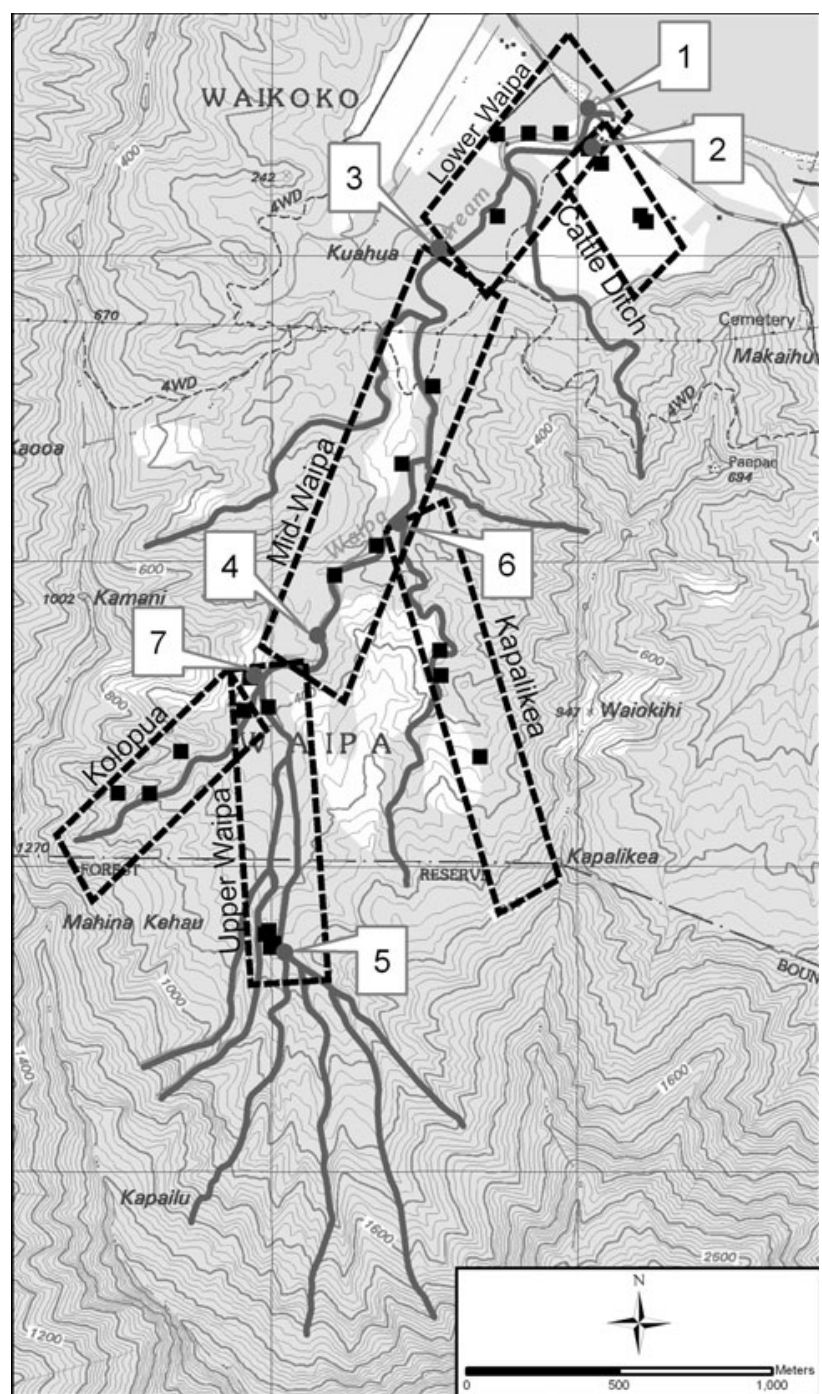

Figure 2. Plot locations and water quality monitoring sites.

Stream $(n=4)$, and at the confluence of Kapalikea $(n=1)$ and Kolopua $(n=1)$ tributaries above Waipā Stream. Weather stations were established at mid- $(200 \mathrm{~m})$ and lower $(1 \mathrm{~m})$ Waipā watershed locations to record solar radiation $(\mathrm{kW})$ and rainfall $(\mathrm{cm})$ every hour from April 1 , 2004 to April 30, 2005. Riparian plots were adjacent to stream monitoring sites at the end of stratified sections along Waipa Stream, at the confluence of two tributaries directly above Waipā Stream, and at the end of a cattle pasture irrigation diversion ditch directly above Waipā Stream mouth.

Cattle were observed near $(<100 \mathrm{~m})$ stream monitoring sites 1, 2, and 3 daily from June 1, 2004 to August 31, 2004, and daily from January 1, 2005 to August 1, 2005. Neither cattle nor cattle sign were ever observed within $100 \mathrm{~m}$ of sites 4, 5, 6, and 7 during all site visits throughout the same monitoring periods for cattle at sites 1,2 , and 3 .

\section{Stream Monitoring Site Data Collection}

Stream Enterococcus Concentration

Stream water samples from each of seven stream monitoring sites were collected on July 9 and 23, 2004, February 9, 2005, March 9 and 23, 2005, and June 1, 2005 at approximately 8:30 a.m. Hawaii time to capture historically dry (June and July) and wet (February and March) seasons. Three replicate $100 \mathrm{ml}$ water samples were collected from each monitoring site on each sample collection date (APHA, 2005) to take into account variability of sampling and testing (repeatability/reproducibility of microbiological analyses). Samples were analyzed for Enterococcus using the quantitative Enterolert IDEXX method, which produces estimates of the most probable number of cells present in water samples with $100-\mathrm{ml}$ volumes (USEPA, 2003). Samples were diluted 10 to 1 with a sterile buffered solution February 9, 2005, March 9, 2005, and March 23, 2005 due to concerns that increased fecal surface runoff during the historically wet season would exceed the upper detection limit of the analytic procedure. Samples collected during the historically dry season (July 9 , 2004, July 23, 2004, and June 1, 2005) were not diluted based on the assumption that Enterococcus levels would not exceed the upper detection limit. If Enterococcus (MPN/100 ml) concentrations were $<1 \mathrm{MPN} / 100 \mathrm{ml}$, we used a surrogate value of $0.1 \mathrm{MPN} / 100 \mathrm{ml}$ for statistical analyses.

\section{Stream Turbidity, Dissolved Oxygen, and Salinity}

At each of the same seven water quality monitoring sites selected for Enterococcus analysis, we conducted triplicate measurements of turbidity (Oakton Turbidimeter T-100, Oakton Instruments, Vernon Hills, IL, recording in NTU), as well as salinity (ppt) and dissolved oxygen (mg/L) (YSI MPS Multipurpose sensor 556 model, YSI Incorporated, Yellow Springs, OH) on July 11 and 17, 2004, February 21, 2005, March 15 and 22, 2005, and June 1, 2005 to take into account variability of sampling and testing (repeatability/reproducibility of chemical analyses). Results found to have a log normal error distribution were reported as a geometric mean.

\section{Riparian Monitoring Plot Data Collection}

\section{Canopy Cover}

Within each of the 24 riparian monitoring plots, we oriented three transects parallel to the stream channel at the 
streambank edge, midway, and at the uppermost edge of the plots. We measured canopy cover in each plot 2 days/ week, in July and August 2004, using a densitometer every $50 \mathrm{~cm}$ along each transect, for a total of 63 observations of canopy cover per $10 \times 10 \mathrm{~m}$ plot, and 33 observations of canopy cover per $5 \times 5 \mathrm{~m}$ plot. Tributary plot sizes were adjusted to $5 \times 5 \mathrm{~m}$ due to reduced riparian area size.

\section{Surface Soil and Cattle Manure Enterococcus Concentrations}

Four composite soil samples were collected on July 18-July 22, 2005, July 25-27, 2005, August 1, 3, 4, and 16, 2005 from the soil surface layer $(0-10 \mathrm{~cm}$ deep) once in each riparian plot with a sterile spatula. Samples were placed in sterile containers, stored on ice, and analyzed within $8 \mathrm{~h}$ of collection for Enterococcus (MPN/g soil) following the protocol described by Shibata et al. (2004). We modified the Shibata et al. (2004) method by using $3 \mathrm{~g}$ of soil for composited soil subsamples (see below), rather than $10 \mathrm{~g}$. Approximately $3 \mathrm{~g}$ of soil from each composite sample per plot was combined and thoroughly mixed to create a $12-\mathrm{g}$ composite subsample for each riparian plot for each sample date. Three grams of this subsample was mixed with $100 \mathrm{ml}$ of sterile dispersant solution $(0.15 \mathrm{M} \mathrm{NaCl})$ and shaken for $120 \mathrm{~s}$ to disperse microbes into the liquid phase and filtered with a 30- $\mu \mathrm{m}$ pore-size nylon mesh filter (Type NY30, Millipore, Bedford, MA), for a total of 24 composite soil subsamples analyzed for Enterococcus. With dilution factors taken into account for the $100 \mathrm{ml}$ of filtrate $(10 \mathrm{ml}$ soil solution/90 ml sterile buffered water), the limit of detection was $<3.3 \mathrm{MPN} / \mathrm{g}$ of soil. For data analysis, values of $<3.3 \mathrm{MPN} / \mathrm{g}$ soil were recorded as 0.1 for statistical analyses (the geometric mean was calculated as $[\mathrm{n} \times 0.1+\operatorname{sum}($ soil samples with values $>3.3 \mathrm{MPN} / \mathrm{g})] /$ 24 , where $n=$ the number of soil samples with $<3.3$ $\mathrm{MPN} / \mathrm{g}$ soil). The same methods for testing soil for Enterococci were applied as a control for soil methods to fresh cattle manure samples $(n=8)$ collected from the cattle pasture on August 1, 3, 4, 6, and 16, 2005. For data analysis, values of $>80,654 \mathrm{MPN} / \mathrm{g}$ cattle manure were recorded as $80,655 \mathrm{MPN} / \mathrm{g}$ in order to report the minimum, arithmetic mean, and maximum.

\section{Statistical Analysis}

Summary statistics were calculated (geometric mean and standard deviation) for the various field plot characteristics and stream monitoring data per section and per site
(Fig. 2). Next, linear mixed effects regression analysis was done on the program S-Plus 2000 (TIBCO Spotfire, Somerville, MA) to identify climate, water chemistry, and various plot-specific factors that were associated $(P<0.05)$ with the geometric mean concentration of Enterococcus (MPN/g) in adjacent stream water samples. Linear mixed effects regression analysis (Pinheiro and Bates, 2000) is a statistical model well suited to water quality and other environmental research, where investigators repeatedly sample a set of locations and want to determine if a water quality or other environmental parameter are associated $(P<0.05)$ with one or more land use patterns, climate measurements, geomorphological attributes, or other such independent factors operating at the plot-, field-, or watershed-scale. The results of the model (coefficients, $P$-values, 95\% confidence intervals) are adjusted for the amount of correlation within the dataset induced by repeated sampling of a set of sites, in essence, a repeated measures adjustment (Pinheiro and Bates, 2000). This regression model has been successfully used to identify the association between dairy farm management practices and fecal coliform levels in farm runoff for coastal watersheds (Lewis et al., 2005); to identify rangeland parameters that correlate with amount of livestock fecal deposition on rangelands (Tate et al., 2003), fecal bacteria loads discharged from annual grasslands under rainfall runoff conditions (Atwill et al., 2003; Tate et al., 2000, 2006); and to identify which management practice reduces fecal bacteria in irrigated pasture runoff (Knox et al., 2007).

Using linear mixed effects regression, we determined if average rainfall ( $\mathrm{cm} /$ hour) over the previous 30 days, 24hour average solar radiation $(\mathrm{kW})$ at $1 \mathrm{~m}$ and $200 \mathrm{~m}$ elevation, canopy cover (\%) at the plot location, turbidity (NTU), dissolved oxygen (mg/L), salinity (ppt) of the stream water, Enterococcus (MPN/g) concentration in the riparian soil surface at the plot location, and presence of cattle $<100 \mathrm{~m}$ from stream monitoring sites were associated $(P<0.05)$ with the geometric mean concentration of Enterococcus (MPN/100 ml) in adjacent stream water samples (Pinheiro and Bates, 2000). These various climate, water chemistry, and plot-specific factors functioned as the independent variables, while geometric mean concentration of Enterococcus (MPN/100 ml) in the water sample was the dependent variable, and sample site functioned as the group variable. Given that stream water samples were collected in triplicate at each site for each sampling event (e.g., three consecutive water samples), and Enterococcus was measured for each of the three samples, we built our regression model by generating a geometric mean of the triplicate 
Enterococcus concentrations for each site and sampling event and then conducted the statistical analysis, in effect reducing the sample size to one-third, which generates a representative value for the Enterococcus concentration for a site at a specific time. A forward-stepping approach was used to develop a final model, with $P \leq 0.05$ set as the criterion for inclusion of the independent variables into the final model based on a conditional $t$-test (Pinheiro and Bates, 2000). Assumptions of normally distributed error terms and constant variance in error terms were confirmed by graphical evaluation of standard diagnostic plots.

\section{Results AND Discussion}

Enterococcus (MPN/g) in surface soil from plots near the sampled stream was not $(P=0.32)$ associated with the geometric mean concentration of Enterococcus (MPN/ $100 \mathrm{ml}$ ) in stream surface water. Twenty-four hour average mid-elevation solar radiation ( $P=0.65), 24$-hour average near sea level solar radiation $(P=0.06), 30$-day average rainfall near sea level $(P=0.22), 30$-day average rainfall at mid-elevation $(P=0.17)$, turbidity $(P=0.70)$, dissolved oxygen $(P=0.09)$, and presence or absence of cattle $(P=0.12)$ were also not associated with the geometric mean concentration of Enterococcus (MPN/100 ml) in stream surface water.

The lowest geometric mean concentrations of Enterococcus (MPN/100 ml) in stream surface water were found at site 5 on 5/6 sampling events, with a geometric mean of 7 Enterococcus (MPN/100 ml) at site 5 (Table 1). Highest geometric mean concentrations of Enterococcus (MPN/ $100 \mathrm{ml}$ ) in stream surface water were found at site 1 on 5/6 sampling dates, with a geometric mean of 307 Enterococcus (MPN/100 ml) at site 1 (Table 1).

The highest geometric mean dissolved oxygen $(\mathrm{mg} / \mathrm{L})$ was recorded at site 4 on 6/6 sampling dates (Table 2). The highest geometric mean turbidity (NTU) was recorded at site 2 on $4 / 6$ sampling dates (Table 2). The highest geometric mean salinity was recorded at site 1 on $6 / 6$ sampling dates (Table 2).

Month $(P=0.041)$, canopy cover \% $(P=0.006)$, and salinity $(P=0.004)$ were associated with the geometric mean of Enterococcus (MPN/100 ml) in water samples (Table 3). Each unit decrease in salinity (ppt) was associated with a $68.2 \mathrm{MPN} / 100 \mathrm{ml}$ increase in the geometric mean of Enterococcus in-stream water concentrations (Table 3). Each 1\% decrease in riparian canopy cover was associated with a $4.6 \mathrm{MPN} / 100 \mathrm{ml}$ increase in the geometric mean of Enterococcus in water samples (Fig. 3). The linear mixed effects regression describing these relationships can be evaluated by comparison of predicted versus observed geometric mean per month of Enterococcus in water samples (Fig. 4). The predictive accuracy of the model decreased as the geometric mean of Enterococcus instream water concentrations increased (Fig. 4).

Culturable organisms, such as Enterococcus and E. coli, are often used as indicators that water is contaminated with feces. However, several studies have noted uncertainties about the suitability of Enterococcus (Shibata et al., 2004) as a fecal indicator in tropical island riparian surface waters. The primary concern is that Enterococcus may be free-living

Table 1. Geometric Means of Enterococcus (MPN/100 ml) in Stream Water $( \pm \mathrm{SD})$

\begin{tabular}{|c|c|c|c|c|c|c|c|}
\hline Date & Site 5 & Site 7 & Site 4 & Site 6 & Site 3 & Site 2 & Site 1 \\
\hline July 9, 2004 & $10(13)$ & $47(10)$ & $75(14)$ & $685(463)$ & $188(148)$ & $388(276)$ & $782(339)$ \\
\hline July 23, 2004 & $13(2)$ & $112(56)$ & $217(80)$ & $435(69)$ & $148(39)$ & $132(151)$ & $472(284)$ \\
\hline February 9, 2005 & $31(11)$ & $99(48)$ & $66(17)$ & $50(68)$ & $32(16)$ & $86(36)$ & $186(59)$ \\
\hline March 9, 2005 & $104(18)$ & $52(30)$ & $133(35)$ & $63(0)$ & $151(73)$ & $50(68)$ & $591(75)$ \\
\hline March 23, 2005 & $1(6)$ & $16(18)$ & $15(6)$ & $17(24)$ & $85(12)$ & $40(47)$ & $34(31)$ \\
\hline June 1, 2005 & $1(2)$ & $14(7)$ & $4(19)$ & $1(2)$ & $31(37)$ & $32(6)$ & $603(210)$ \\
\hline Single sample maximum & 121 & 178 & 276 & 1300 & 387 & 687 & 1203 \\
\hline Single sample minimum & $<1$ & 7.5 & $<1$ & $<1$ & 20 & 10 & 10 \\
\hline
\end{tabular}


Table 2. Geometric Mean, Single Sample Minimum and Maximum of Dissolved Oxygen (mg/L), Turbidity (NTU), and Salinity (ppt) in Stream Water $( \pm \mathrm{SD})$

\begin{tabular}{|c|c|c|c|c|c|c|c|}
\hline Date & Site 5 & Site 7 & Site 4 & Site 6 & Site 3 & Site 2 & Site 1 \\
\hline \multicolumn{8}{|l|}{ Dissolved oxygen } \\
\hline July 11, 2004 & $8.2(0.1)$ & $8.1(0.0)$ & $8.2(1.0)$ & $7.3(0.2)$ & $7.3(0.1)$ & $2.7(0.0)$ & $5.0(0.4)$ \\
\hline July 17, 2004 & $7.9(0.1)$ & $7.6(0.2)$ & $8.0(0.2)$ & $7.7(0.1)$ & $7.6(0.2)$ & $2.7(0.1)$ & $3.8(0.8)$ \\
\hline February 21, 2005 & $9.3(0.3)$ & $9.2(0.1)$ & $9.5(0.0)$ & $9.2(0.1)$ & $9.3(0.2)$ & $4.3(0.1)$ & $6.1(0.7)$ \\
\hline March 15, 2005 & $9.6(0.1)$ & $9.2(0.3)$ & $9.6(0.2)$ & $9.2(0.1)$ & $9.3(0.1)$ & $5.0(0.1)$ & $5.2(0.7)$ \\
\hline March 22, 2005 & $9.1(0.7)$ & $9.1(0.4)$ & $9.7(0.2)$ & $9.1(0.1)$ & $8.3(0.2)$ & $5.2(0.2)$ & $5.4(0.5)$ \\
\hline June 1, 2005 & $9.3(0.5)$ & $8.9(0.2)$ & $9.5(0.5)$ & $9.5(0.1)$ & $8.6(0.3)$ & $3.9(0.2)$ & $6.6(0.4)$ \\
\hline Single sample maximum & 9.8 & 9.4 & 9.8 & 9.8 & 9.3 & 5.3 & 6.9 \\
\hline Single sample minimum & 7.8 & 7.4 & 7.8 & 7.1 & 7.1 & 2.6 & 3.2 \\
\hline \multicolumn{8}{|l|}{ Turbidity } \\
\hline July 11, 2004 & $0.8(0.0)$ & $1.9(0.3)$ & $1.1(0.1)$ & $1.6(0.5)$ & $1.4(0.4)$ & $2.7(0.7)$ & $4.2(1.5)$ \\
\hline July 17, 2004 & $1.1(0.1)$ & $2.3(0.3)$ & $1.3(0.2)$ & $1.4(0.1)$ & $1.7(0.4)$ & $5.1(2.2)$ & $3.0(0.8)$ \\
\hline February 21, 2005 & $1.5(0.2)$ & $4.1(0.3)$ & $1.8(0.3)$ & $4.1(0.3)$ & $1.9(0.2)$ & $3.9(1.0)$ & $3.2(0.1)$ \\
\hline March 15, 2005 & $1.1(0.1)$ & $2.2(0.1)$ & $1.3(0.1)$ & $1.5(0.2)$ & $0.9(0.2)$ & $4.6(2.3)$ & $1.9(0.2)$ \\
\hline March 22, 2005 & $3.3(0.4)$ & $6.6(0.1)$ & $3.3(0.3)$ & $4.2(0.2)$ & $5.3(2.0)$ & $16.1(18.8)$ & $3.4(0.2)$ \\
\hline June 1, 2005 & $1.6(0.2)$ & $3.5(0.0)$ & $1.7(0.0)$ & $2.5(0.1)$ & $2.9(1.9)$ & $12.7(12.3)$ & $3.1(0.5)$ \\
\hline Single sample maximum & 3.7 & 6.7 & 3.6 & 4.4 & 7.3 & 37.6 & 5.8 \\
\hline Single sample minimum & 0.8 & 1.6 & 1.0 & 1.2 & 0.7 & 1.9 & 1.8 \\
\hline \multicolumn{8}{|l|}{ Salinity } \\
\hline July 11, 2004 & $0.0(0.0)$ & $0.1(0.0)$ & $0.0(0.0)$ & $0.1(0.0)$ & $0.1(0.0)$ & $0.1(0.0)$ & $0.4(0.1)$ \\
\hline July 17, 2004 & $0.0(0.0)$ & $0.1(0.0)$ & $0.0(0.0)$ & $0.1(0.0)$ & $0.1(0.0)$ & $0.1(0.0)$ & $0.5(0.1)$ \\
\hline February 21, 2005 & $0.0(0.0)$ & $0.1(0.0)$ & $0.0(0.0)$ & $0.1(0.0)$ & $0.1(0.0)$ & $0.1(0.0)$ & $11.3(8.9)$ \\
\hline March 15, 2005 & $0.0(0.0)$ & $0.1(0.0)$ & $0.0(0.0)$ & $0.1(0.0)$ & $0.1(0.0)$ & $0.1(0.0)$ & $1.0(0.5)$ \\
\hline March 22, 2005 & $0.0(0.0)$ & $0.1(0.0)$ & $0.0(0.0)$ & $0.1(0.0)$ & $0.1(0.0)$ & $0.1(0.0)$ & $6.2(5.0)$ \\
\hline June 1, 2005 & $0.0(0.0)$ & $0.1(0.0)$ & $0.0(0.0)$ & $0.1(0.0)$ & $0.0(0.0)$ & $0.1(0.0)$ & $0.1(0.0)$ \\
\hline Single sample maximum & 0.0 & 0.1 & 0.0 & 0.1 & 0.1 & 0.1 & 17.2 \\
\hline Single sample minimum & 0.0 & 0.1 & 0.0 & 0.0 & 0.0 & 0.1 & 0.1 \\
\hline
\end{tabular}

Upper Elevation.

in tropical island soil environments (Hardina and Fujioka, 1991; Fujioka et al., 1999), which would mean that occurrence of the organisms in a water sample could be the result of naturally occurring bacterial populations rather than fecal contamination. Researchers have proposed that soil is a major environmental source of Enterococcus in tropical islands. Whereas we found no Enterococcus in riparian soils in 18 out of a total of 24 composite subsamples from 24 plots throughout the study period $(\min =<3.3 \quad \mathrm{MPN} / \mathrm{g} \quad[n=18 \quad$ plots $], \quad$ geometric mean $=0.40 \mathrm{MPN} / \mathrm{g} \quad[\mathrm{SD}=0.08], \quad \max =17.3 \mathrm{MPN} / \mathrm{g}$ $[n=1])$, we also found no association between riparian soil Enterococcus concentrations and those in nearby stream locations during sampling in 2004 and 2005. Because 75\% of the soil samples tested were below the detectable limit and we used $0.1 \mathrm{MPN} / \mathrm{g}$ as a value for soil samples below the limit of detection, our geometric mean value for all plots was below the limit of detection with a geometric mean of $0.40 \mathrm{MPN} / \mathrm{g}$.

Presence of cattle near sites 1 and 2 (Fig. 2), lowest geometric mean riparian canopy cover $\%$ along the cattle ditch section (Fig. 2) (Table 4), and irrigation water transport through site 2 to site 1 led to higher geometric mean of Enterococci in-stream water concentrations at site 1 than site 5 (Table 1). The very high Enterococci (MPN/g) concentrations for cattle manure samples $(n=8)$ $(\min =178.9$, arithmetic mean $=23,426, \max =80,655$ $[n=2]$ ) along with nearby presence of potential septic 
Table 3. Linear Mixed Effects Regression Model of Canopy Cover (\%), Month, and Salinity on Enterococcus (MPN/100 ml) Geometric Mean Concentrations in Waipā Watershed during 2004 and 2005

\begin{tabular}{|c|c|c|c|}
\hline Factor & Coefficient $^{\mathrm{a}}$ & $95 \% \mathrm{CI}^{\mathrm{b}}$ & $P$-value ${ }^{\mathrm{c}}$ \\
\hline \multicolumn{4}{|l|}{ Month } \\
\hline February $^{\mathrm{d}}$ & 0.0 & - & - \\
\hline March & -17.8 & $(-138,103)$ & 0.77 \\
\hline June & -42.3 & $(-184,100)$ & 0.55 \\
\hline July & 129 & $(5.6,253)$ & 0.041 \\
\hline Canopy cover $(\%)$ & -4.6 & $(-7.2,-2.0)$ & 0.006 \\
\hline Salinity & -68.2 & $(-112,-24)$ & 0.004 \\
\hline Intercept & 486 & $(281,692)$ & $<0.0001$ \\
\hline
\end{tabular}

${ }^{a}$ Total Enterococcus (MPN/100 ml) per site during the study period of 2004 and 2005 was set as the dependent variable; month, canopy cover (\%), and salinity were set as fixed independent effects. Site identity set as a group effect to account for repeated measures. Coefficients are for total Enterococcus $(\mathrm{MPN} / 100 \mathrm{ml})$ values.

${ }^{\mathrm{b}} \mathrm{CI}$, confidence interval.

${ }^{c}$ Significance (coefficient not equal to 0 ) was determined by $P<0.05$ using a conditional $t$-test.

${ }^{\mathrm{d}}$ Referent condition to which other levels of the categorical factor are compared.

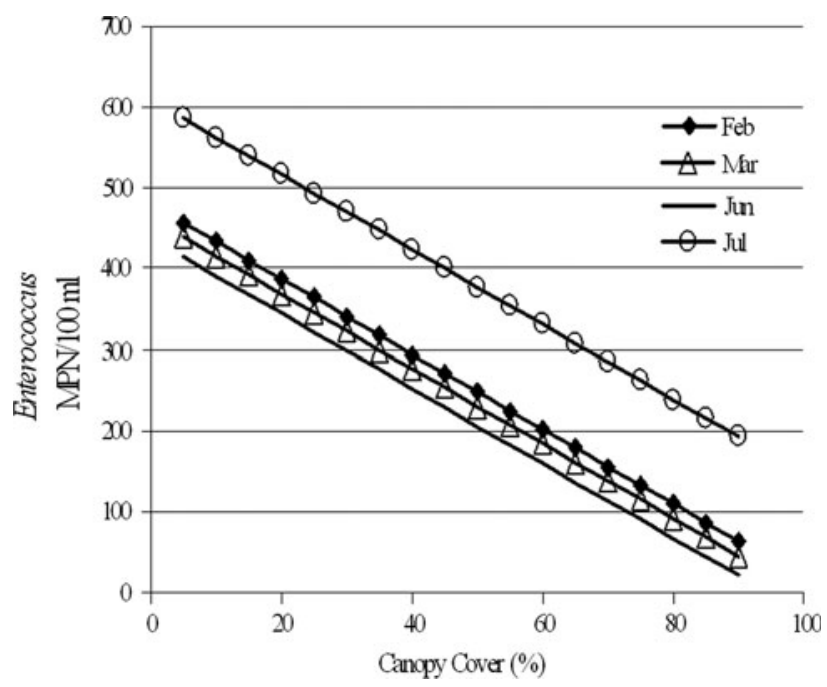

Figure 3. Predicted geometric mean Enterococcus (MPN/100 ml) concentrations as a function of canopy cover \% and month with salinity set as 0.1 ppt.

leaching, may also contribute to the highest geometric mean Enterococci concentrations in water samples at site 1, because of the influence of the cattle pasture diversion ditch conveying surface runoff to site 1 from site 2 , and the influence of potential human fecal input directly above site 1 from residents and visitors. The geometric mean for

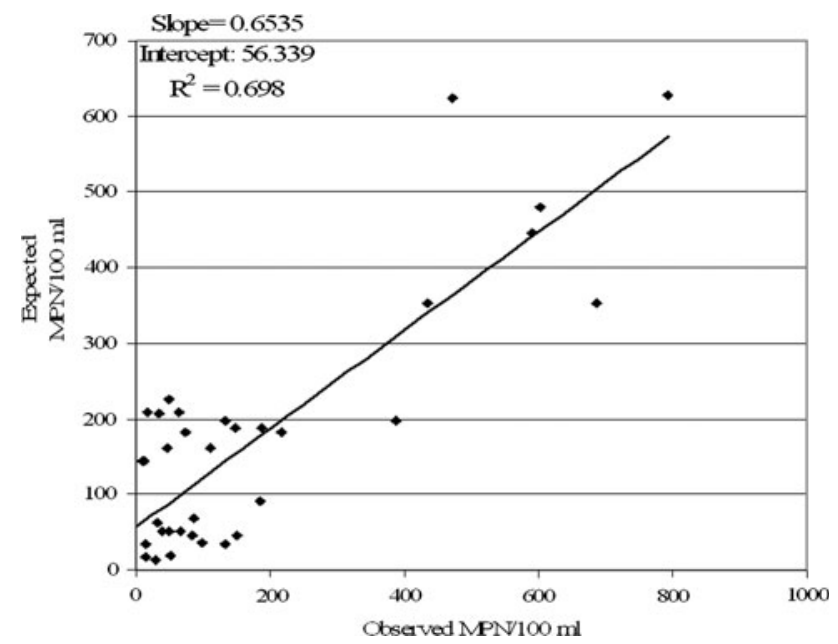

Figure 4. Predicted geometric mean Enterococcus (MPN/100 ml) as a function of canopy cover $\%$ and month with salinity set as $0.1 \mathrm{ppt}$.

Table 4. Geometric Mean of Canopy Cover \% $( \pm S D)$

\begin{tabular}{lc}
\hline Section & $\%( \pm \mathrm{SD})$ \\
\hline Cattle ditch & $14.3(12.4)$ \\
Lower Waipā & $99(1.4)$ \\
Mid-Waipā & $96.8(5.2)$ \\
Upper Waipā & $94.8(2.1)$ \\
Kapalikea tributary & $51.5(41.3)$ \\
Kolopua tributary & $93.3(4.5)$ \\
\hline
\end{tabular}

salinity at site 1 at Waipā Stream mouth was highest due to salt water intrusion from Hanalei Bay (Table 2). Geometric mean for turbidity was highest at site 2 , possibly due to erosion and compaction of the soil surface by cattle (Table 2), and lowest geometric mean canopy cover \% directly above site 2 (Table 4). Geometric mean dissolved oxygen was highest at site 4 (Table 2) in a heavily forested section of mid-Waipā Stream above presence of cattle.

Feral pigs clustering near a major food source of $P$. cattleianum, in upper reaches of Kapalikea tributary during July 2004, may have caused differences in Enterococcus (MPN/100 ml) concentrations from July, versus other months, due to migration of pigs to stream corridors during fruiting of $P$. cattleianum at that time. P. cattleianum dominated canopy cover in Waipā Stream and tributaries compared to all other canopy species.

Continued research on movement, reproduction, and survival of fecal bacteria and pathogens through tropical island watersheds in fresh, estuarine, and marine waters could improve knowledge about, and application of, 
management practices such as buffer zones for decreasing microbial contaminants to ambient waters. This could be accomplished by evaluating cattle feces distribution patterns relative to hydrologic, topographic, and other variables to determine how land use is causally connected to microbial surface water quality (Tate et al., 2003), while incorporating current techniques for direct enumeration of pathogens by fluorescent staining and nucleic acid analysis, and developing tropical maximum contaminant levels for certain resistant pathogens in tropical waters (Hazen, 1988). Identifying how Enterococcus enters nearshore waters will help environmental managers address pressing water quality issues, including exceedances of Enterococcus water quality standards (Knee et al., 2008). Given concerns that Enterococci monitoring and recording of geometric mean for statistical analyses in fresh and marine waters could falsely indicate fecal contamination under USEPA guidelines (1986), it would help to determine their longevity, particularly in conditions found on rural tropical islands. If the source of Enterococcus is soil and not feces, further research is needed to determine if Enterococcus from soil can contaminate food for domestic and feral animals. But data from this research indicated that Enterococcus concentrations $(\mathrm{MPN} / \mathrm{g})$ are much higher in cattle manure than in surface soil, and that by decreasing riparian canopy cover \%, Enterococcus geometric mean concentrations in stream water could increase, perhaps due to overgrazing near streams, removal of riparian zone canopy, and increased fecal surface runoff due to soil compaction. It is possible that previous contamination, followed by degradation and disappearance of the fecal matrix, may leave Enterococci in tropical island soils even though feces do not appear to be present.

\section{OPEn Access}

This article is distributed under the terms of the Creative Commons Attribution Noncommercial License which permits any noncommercial use, distribution, and reproduction in any medium, provided the original author(s) and source are credited.

\section{REFERENCES}

American Public Health Association (APHA) (2005) Standard Methods for the Examination of Water and Wastewater, sec. 9.21, 21st ed., Washington, DC: APHA
Ashbolt NJ (2004) Microbial contamination of drinking water and disease outcomes in developing regions. Toxicology 198:229-238

Atwill ER, Hoar B, Pereira MGC, et al. (2003) Improved quantitative estimates of low environmental loading and sporadic periparturient shedding of Cryptosporidium parvum in adult beef cattle. Applied Environmental Microbiology 68:4604-4610

Byappanahalli M, Fujioka R (2004) Indigenous soil bacteria and low moisture may limit but allow faecal bacteria to multiply and become a minor population in tropical soils. Water Science and Technology 50:27-32

Fujioka R (2001) Monitoring coastal marine waters for sporeforming bacteria of faecal and soil origin to determine point from non-point source pollution. Water Science and Technology 44:181-188

Fujioka R, Sian-Denton M, Borja M, Castro J, Morphew K (1999) Soil: the environmental source of Escherichia coli and Enterococci in Guam's streams. The Journal of Applied Microbiology Symposium Supplement 85:83S-89S.

Hardina CM, Fujioka RS (1991) Soil: the environmental source of Escherichia coli and Enterococci in Hawai'i's streams. Environmental Toxicology and Water Quality: An International Journal 6:185-195

Hazen T (1988) Fecal coliforms as indicators in tropical waters: a review. Environmental Toxicology 3:461-477

Knee KL, Layton AB, Street JH, Boehm AB, Payton A (2008) Sources of nutrients and fecal indicator bacteria to nearshore waters on the north shore of Kaua'i (Hawai'i, USA). Estuaries and Coasts 31:607-622

Knox A, Tate KW, Dahlgren RA, Atwill ER (2007) Management reduces E. coli in irrigated pasture runoff. California Agriculture 61:159-165

Lewis DJ, Atwill ER, Lennox MS, et al. (2005) Linking on-farm dairy management practices to storm flow fecal coliform loading for California coastal watersheds. Environmental Monitoring and Assessment 107:407-425

Pinheiro JC, Bates DM (2000) Mixed-Effects Models in S and SPLUS, New York: Springer

Shibata T, Solo-Gabriele H, Fleming L, Elmir S (2004) Monitoring marine recreational water quality using multiple microbial indicators. Water Research 38:3119-3131

Tate K, Atwill ER, McDougald NK, George MR (2003) Spatial and temporal patterns of cattle feces deposition on rangeland. Journal of Rangeland Management 56:432-438

Tate KW, Pereira MGC, Atwill ER (2000) Efficiency of vegetated buffer strips to improve the quality of runoff from irrigated pastures. Journal of Soil and Water Conservation 55:473-478

Tate KW, Atwill ER, Bartolome JW, Nader GA (2006) Significant E. coli attenuation by vegetative buffers on annual grasslands. Journal of Environmental Quality 35:795-805

U.S. Environmental Protection Agency (USEPA) (1986) Ambient Water Quality Criteria for Bacteria. EPA440/5-84-002, Washington, DC: Office of Water, Regulations and Standards, Criteria and Standards Division, USEPA

U.S. Environmental Protection Agency (USEPA) (2003) Guidelines Establishing Test Procedures for the Analysis of Pollutants, Analytical Methods for Biological Pollutants in Ambient Water; Final Rule. U.S. Federal Register- 40 CFR Part 136, Vol. 68, No. 139, Washington, DC: USEPA 